\title{
Beyond graduation: The trajectories of graduates in North Wales
}

Teresa Crew*

Bangor University

\begin{abstract}
Higher Education $(\mathrm{HE})$ is in a state of transformation, with the economic recession leading to an even greater emphasis on graduate outcomes. Despite a proliferation of literature relating to under-represented groups 'getting ready for', 'getting into' and 'staying in' $\mathrm{HE}$, less attention has been devoted to how they 'get on', post graduation, particularly in the long term. Existing UK research suggests that graduate opportunities are influenced by pre-entry characteristics, institution attended and subject studied. However it is noted that the majority of studies focus on first destinations (six months after graduation). This reflects the first six months after graduation and single outcomes. As a result this ESRC-funded study investigated graduates' long term trajectories up to four years after graduation. The mixed methods study focused on graduates from three different types of degree awarding institutions in North Wales and on three specific subjects - chosen for contrast and convenience. Half of the sample self identified as being non-traditional students. The study revealed that those graduates who defined themselves as being non-traditional students were more likely to have multiple outcomes or be in temporary employment, to have disrupted trajectories and lack social networks. This has serious implications for wider issues of social justice within education.
\end{abstract}

Key words: non-traditional students; graduates; widening participation; social capital; cultural capital.

\section{Introduction}

Widening participation in Higher Education (HE) has been a central feature of subsequent governments since World War Two, including both the previous Labour (1997-2010) and current Coalition Government education policy (2010 to present) (Bathmaker, Ingram and Waller, 2013). The Dearing Report ${ }^{1}$ (1997) made recommendations regarding the purpose, structure and funding of $\mathrm{HE}$, the overall aims being to both increase the overall proportion of people accessing higher education and address patterns of under-representation in higher education (Thomas et al., 2005). As widening participation policies were underpinned by an emphasis on social mobility they were promoted to potential students as being a mechanism to increase life 
chances (David et al., 2008) and labour market opportunities (Kennedy, 1997). Despite the introduction of university tuition fees this expansion has been rapid. The last twenty years demonstrates this, as 17 per cent of the population had a degree qualification in 1993, compared with 38 per cent in 2013 (ONS, 2013). The article begins with a discussion of research relating to non-traditional students and graduates. After introducing the methodology this paper focuses on HESA statistical data on graduates from North Wales from the sample institutions and subjects and goes on to outline the long term trajectories of this sample of graduates. The final section returns to the issue of widening participation.

\section{Current research on non-traditional students}

\section{The use of the term non-traditional student}

Changes to social demographics in HE led to Benn (1995) first proposing the term 'non-standard' to describe students who may have benefited from widening participation policies. However, it is Morey et al's (2003: 4) category of 'non-traditional student' that offers the more commonly used profile of those who have population characteristics not normally associated with higher education. Morey et al (2003) defines such students as being those from lower socio-economic backgrounds; mature and/or first generation students; ethnic minorities and individuals with disabilities. Whilst this definition is the most comprehensive there are still difficulties. When we consider the 'case' of mature students Thomas and Quinn (2007) note there are international variations in terms of the cited upper age range e.g. 21 in the UK; 23 in Ireland; 24 in the US and 25 in Australia. Also, while age is often linked with economic disadvantage, not all mature students are economically disadvantaged and some may have delayed their university education due to their families or career. Non-traditional students are also often pathologised as different or deficient (see Leathwood and O'Connell, 2003) or as having complex support needs (see Newson, McDowall and Saunders, 2011). This is despite the observation by Barrow (2011) that non-traditional is now the norm in post 1992 and less prestigious institutions. Whilst there is a much more balanced understanding of this cohort in other studies (e.g. McGivney, 2004; Field and Morgan-Klein, 2010; Moore, Sanders and Higham, 2013), the dominant discourse on non-traditional students in HE focuses on academic failure rather than success (Reay, 2001: 1). Whilst non-traditional students is a useful identifying term, the approach taken in this study is to present them as individuals.

\section{Graduate outcomes}

Current research states that opportunities are often dependant on pre-entry factors, the institution attended and subject studied (Tomlinson, 2007). The pervasive influence of social and economic background (Purcell et al., 2013: 192) is significant because, as outlined, there has been a concerted policy effort to widen participation to non-traditional students. Smith, McKnight and Naylor (2000) evaluated HESA data for the 1999 full UK cohort of graduates. They found that the probability of unemployment six months after graduation was influenced strongly by the person's economic background - those from disadvantaged groups being more likely to be unemployed. HESA data from 2011/12 also showed that, as with previous years, male graduates were more likely to be unemployed six months after leaving university than women. Socio-demographic factors also influence entry into postgraduate study, as Wakeling and Kyriacou (2010) found that postgraduate students were disproportionately male and from higher social classes. The age of a graduate is an additional factor that can influence graduate outcomes. Pennington, Mosely and Sinclair's (2013) research on 
transition to the labour market found that mature graduates (those aged over 24) were more likely to be unemployed. Institutional effects are discussed by Power et al (2003) who mapped the educational pathways and subsequent entry into employment of 350 young men and women. They found that those who were 'doing well' in the first six months after graduation had gone to elite and 'old' universities. However, Chevalier and Conlon (2003) note that there is less difference in outcomes between graduates who attend less prestigious institutions. The relationship between degree subject and outcomes is also significant. Brennan, Williams and Blasko (2003) analysed the 2000/01 findings of the HESA First Destinations Survey (FDS), concentrating on graduates with a first degree in subjects that included Sociology and Business Studies. They found that graduates in business studies had the highest levels of employment six months after graduation, whilst those with a social studies degree had high levels of engagement with postgraduate study.

The reasons cited for graduates from non-traditional backgrounds facing difficulties post graduation are varied. Lido et al (2008) considered that the employability skills of this cohort are a concern, noting that they are less likely to participate in activities to increase employability (cited in Tibbey, 2012: 7). Whilst a wide range of employability skills are useful for graduates, findings from 'University Challenge: How Higher Education Can Advance Social Mobility' a report conducted by Alan Milburn, on behalf of the Social Mobility and Child Commission (2012) suggest that employers are looking for not only academic qualifications, but also work experience and extra-curricular activity. These are skills that Stevenson and Clegg (2011) state can be difficult for working-class students and those with caring responsibilities to develop. In addition to the need for employability skills, the Social Mobility and Child Commission (2012) suggest a lack of family connections is a factor that can disadvantage some graduates. This finding ties in neatly with Pierre Bourdieu's thesis that cultural capital is unequally distributed (Bourdieu, 1973). The amount of cultural capital that an individual "inherits" from their family of origin is a function of their socio-economic status (Bourdieu, 1979). The gaining of a degree qualification is one example of capital. However, as access to university has become commonplace, students from high socioeconomic status backgrounds are able to draw upon additional forms of capital, such as well-resourced social networks in order to stay ahead of the newcomers (Reay, 1998; Reay, David and Ball (2005): resources that are less likely to be available to graduates from non-traditional backgrounds.

\section{The research study}

Graduates from a traditional, a post 1992 and a distance learning institution were selected for the study. ${ }^{2}$ There were institutional differences in terms of the student cohort, for instance full-time students form the majority in the traditional institution, whilst in the post 1992 institution and the distance learning university part-time study predominates. There were also similarities as all institutions had a good representation of local and mature students and those who were on low incomes (HESA, 2011). This is consistent with statistics on Welsh institutions as these tend to have higher proportions of students from low participation neighbourhoods and students who receive a disabled students' allowance (Higher Education Funding Council for Wales, 2010: 1). When considering the subject areas, in contrast to Brennan, Williams and Blaskó (2003) who concentrated on graduates with similar career paths, this study evaluates graduates from subject areas that might be associated with different career trajectories. Business and administrative studies ${ }^{3}$ was chosen as it is described as a vocational degree that is highly transferable. As successive UK Governments have been keen to increase the number of STEM (science, technology, engineering and 
mathematics) students at British universities a STEM subject was chosen, in this case Engineering and Technology. ${ }^{4}$ Finally as the literature review highlighted that Social Studies $^{5}$ graduates have a healthy engagement with further study, this subject area was included. The ESRC funded study followed a three-stage design which is discussed below.

\section{Phase 1: Analysing Higher Education Statistical Agency (HESA) statistics}

The number and destinations of graduates from the aforementioned institutions and subjects were mapped using information from a bespoke data request relating to the 2007/08 cohort. This year was chosen so that the second stage of the study could draw out longitudinal data for a period of up to four years after graduation. HESA statistics have many advantages, not least that they are effectively a census of individuals as all UK and EU graduates are contacted six months after graduation to find out what they are doing in terms of work and study ${ }^{6}$ HEFCW, 2013).

\section{Phase 2: Self-completion questionnaire}

A self-completion questionnaire was chosen as it is a versatile method of collecting data. It can be sent and returned by post or email, completed via the internet, or by the respondent immediately on the spot (Phellas, Bloch and Seale, 2011: 182-183) - all ways in which the questionnaire was eventually used. The questionnaire identified broad trends and provided some detail of the lived experience of the graduates. Each institution was contacted regarding accessing contact details of graduates, who resided in the UK at the time of their study, from the aforementioned subject areas (2007/08 cohort). The traditional university, being the host institution, allowed access to alumni records. After cleaning the data by removing graduates from outside of the UK, 210 potential respondents ${ }^{7}$ were contacted via post and email. The remaining two institutions did not provide access to alumni records but agreed to pass details of the study on to their graduates. Existing contacts within North Wales and social media tools were also used to promote the study to potential respondents. A total of 66 respondents completed the survey: half (34) were from the traditional institution; ${ }^{8}$ the second largest group were from the post 1992 university (23); and the remainder were from the distance learning institution (9). ${ }^{9}$ Social studies graduates (33) formed the majority in terms of subjects; followed by 24 from business and administration subjects and 9 with an engineering degree. The sample varied considerably from HESA statistics on graduates as the majority were female and half were aged 25 and over. Whilst comprehensive data was not collected regarding degree classification, it is important to note that non-traditional students were proportionally more likely to cite that they had a first or 2:1 degree classification.

\section{Phase 3: Semi-structured interviews}

Semi-structured interviews were then conducted so as to collect qualitative responses. Pilot interviews were conducted to refine interview questions and technique. Interviewees comprised graduates who completed the questionnaire and selected the box saying they would participate in further parts of the study. In total 15 graduates were interviewed. There was an even gender split (eight females, seven males), and all but two interviews were carried out with mature graduates. Interviews were evenly spread across subject areas (five interviews for each subject), but more were conducted with graduates from the traditional and post 1992 institutions (six each) compared with the distance learning institution. Interviews were transcribed into a Microsoft Word document and NVivo was used to analyse the qualitative data. The 
following section discusses the data collected and analysed as part of phase one of the research process.

\section{First destinations of graduates from North Wales}

Table 1 outlines Higher Education Statistical Agency statistics on the circumstances six months after graduation, or 'first destinations' of full-time, first degree graduates from the target institutions. A total of 593 graduates gained a degree in the aforementioned subjects from the three institutions. A slight majority were from the post 1992 institution (276), followed by graduates from the traditional institution (253), whilst the remainder were from the distance learning institution (53). In the post 1992 institution, graduates with an engineering degree formed the majority, whilst business graduates were the majority at the traditional institution as were social studies graduates at the distance learning institution.

Table 1: HESA statistical data on the First destinations of graduates in Business, Engineering and Social studies, from the targets institutions, 2007/08

\begin{tabular}{|c|c|c|c|c|c|c|c|c|c|}
\hline \multirow{2}{*}{$\begin{array}{l}\% \\
\text { Subject }\end{array}$} & \multicolumn{3}{|c|}{ Traditional institution } & \multicolumn{3}{|c|}{ Post 1992 institution } & \multicolumn{3}{|c|}{$\begin{array}{c}\text { Distance Learning } \\
\text { institution }\end{array}$} \\
\hline & 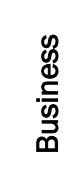 & 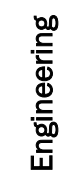 & 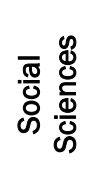 & 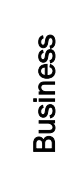 & 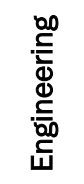 & 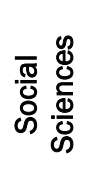 & 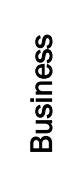 & 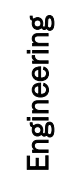 & 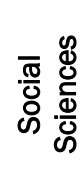 \\
\hline $\begin{array}{l}\text { Full Time } \\
\text { employment }\end{array}$ & 54 & 71 & 54 & 40 & 47 & 46 & 67 & 63 & 40 \\
\hline $\begin{array}{l}\text { Part Time } \\
\text { employment }\end{array}$ & 6 & 0 & 9 & 4 & 2 & 19 & 33 & 0 & 15 \\
\hline $\begin{array}{l}\text { Voluntary } \\
\text { Employment }\end{array}$ & 0 & 0 & 0 & 0 & 0 & 1 & 0 & 0 & 5 \\
\hline $\begin{array}{l}\text { Work \& Further } \\
\text { Study }\end{array}$ & 20 & 10 & 10 & 19 & 15 & 20 & 0 & 21 & 25 \\
\hline Further Study & 7 & 19 & 13 & 28 & 28 & 3 & 0 & 6 & 5 \\
\hline Unemployed & 6 & 0 & 11 & 6 & 6 & 11 & 0 & 5 & 0 \\
\hline $\begin{array}{l}\text { Not available } \\
\text { for employment }\end{array}$ & 7 & 0 & 3 & 0 & 0 & 0 & 0 & 5 & 10 \\
\hline Total & 100 & 100 & 100 & 100 & 100 & 100 & 100 & 100 & 100 \\
\hline
\end{tabular}

Source: HESA, 2011 - Bespoke data request relating to the 2007/08 cohort of graduates from the aforementioned subjects.

Full-time employment was the most common destination for all graduates, but there were variations when destinations were analysed in terms of a combination of institution attended/subject studied. For instance, nearly all (94 per cent) engineering graduates from the distance learning institution were employed, as were almost three quarters of the same graduates from the traditional university, but a number of the engineering graduates from the post 1992 institution went on to further study. Business graduates from the traditional institution had varied destinations in that they were represented in all destination categories except voluntary employment, whilst the post 1992 university had higher percentages of graduates in further study compared 
with the distance learning institution - all of whom were in employment. Social studies graduates from all institutions had the lowest percentages of graduates in full-time employment, the highest in part-time and the largest percentages in unemployment. There were some differences when postgraduate study is compared. Social studies graduates from the post 1992 institution and distance learning college tended to combine further study with employment whilst those from the traditional university tended to choose further study only. There were noted gender and subject differences. Male engineering graduates from the traditional university made up the highest proportions of all graduates who went on to full-time employment, whilst female business graduates from the distance learning institution were most likely to be in parttime employment. Consistent with overall HESA statistics unemployment was found amongst male graduates from most subjects. In terms of postgraduate study, females often chose further study with employment, whilst males were more likely to engage with further study without employment. These differences may be for financial reasons as Wakeling and Kyriacou (2010) found that at doctoral level, 45 per cent of full-time male students were research council funded, as against 31 per cent of women.

Whilst HESA data is useful for describing graduate outcomes six months after graduation, informal conversations with graduates prior to this research study highlighted that some graduates may have more than one destination during the first six months. Thus, the questionnaire was designed so that graduates could provide written details of more than one activity at any given time period. Alongside this, interviews focused on allowing graduates to elaborate on any periods where they had more than one activity during a given time period. The following section presents data collected from Phase 2 and 3 of this study.

\section{The trajectories of graduates from North Wales}

Table 2 outlines the circumstances of the sample of graduates from North Wales, up to four years ${ }^{10}$ after graduation.

Table 2: Post graduation outcomes of all North Wales respondents

\begin{tabular}{lcccc}
\hline Destination (\%) & $\begin{array}{c}\text { Twelve } \\
\text { months }\end{array}$ & Two years & Three years & Four years \\
\hline Full time employment & 32 & 34 & 34 & 36 \\
Part time employment & 3 & 2 & 2 & 1 \\
Voluntary employment & 0 & 0 & 0 & 0 \\
Self employment & 4 & 6 & 6 & 5 \\
Work \& further study & 10 & 10 & 11 & 11 \\
Further study & 4 & 4 & 4 & 4 \\
Unemployment & 4 & 1 & 1 & 1 \\
Not available for & 0 & 3 & 3 & 4 \\
employment & 12 & 9 & 9 & 7 \\
Multiple Outcomes & 68 & 68 & 68 & 68 \\
\hline Total & & & & \\
\hline
\end{tabular}

NB: The categories in the above table in the main relate to HESA publication definitions ${ }^{11}$ However HESA publication categories combine data on self employment along with statistics on full-time employment, whereas I have separated this data. 
Full-time employment remained the dominant outcome each year; unemployment was low and there was healthy engagement with further study. When individual trajectories were analysed, only one quarter of respondents were employed on a fulltime basis throughout the study period of four years. This is because the remainder had periods of further study, part-time employment or even unemployment during their trajectory. There were low, but consistent levels of part-time employment amongst graduates and recorded instances of voluntary employment. The majority of graduates who cited they were self employed did this throughout their trajectory. Postgraduate study accounted for the circumstances of one quarter of respondents, with most combining work with study. There were no graduates giving "unemployed" as their primary activity in year one, who remained unemployed in years two, three and four. Graduates who were 'not available for employment' consisted of a small number of female graduates. The survey and interview data also highlighted a number of key themes.

For instance, one third of respondents had 'multiple outcomes' across the study period. Multiple outcomes are defined as being when a respondent combined more than one activity during the specific time period they were being asked about e.g. every twelve months. This is significant as HESA does not currently allow for graduates to record detail of more than one destination when asked about their circumstances at six months. These multiple outcomes accounted for the circumstances of 17 per cent of respondents in year one and 13 per cent in years two and three. By year four, the level of multiple outcomes had dropped to one in ten graduates. The multiple outcomes were both consecutive, and concurrent. Whilst some respondents provided enough data for me to ascertain the difference, I was not able to gather reliable data on each respondent to determine whether their multiple outcome was consecutive or concurrent. Consecutive multiple outcomes occurred when a graduate was involved in one activity, but then started another activity after completion. For instance, Zoe, ${ }^{12} \mathrm{a}$ female mature graduate is an example of this, as she stated that during the first twelve months she was mainly working full-time, but then had short periods of unemployment. She elaborated to say that she worked on a temporary basis in roles that included being a secretary as well as an assistant for the same organisation. Then when these roles came to an end she had a four to six week period of unemployment. Following this, in year two, she was then offered full-time employment as a data analyst. She was employed in this capacity for approximately eighteen months, but when asked about her current circumstances she stated that she was employed as a Senior Researcher. This data on multiple outcomes shows that the first few years following graduation are not always a straight forward transition from study to employment or further study as there were also graduates who were employed in concurrent multiple outcomes e.g. having more than one activity at the same time in a twelve month period. A typical example of this was Katie who was a stay at home mother, but also volunteered with her local school.

Amongst those who had multiple outcomes over half had been employed on a temporary basis. These graduates reported working for local authorities and the voluntary sector in a mixture of graduate and non-graduate roles. An Organisation for Economic Co-operation and Development publication (2002) on temporary employment promotes it as the solution to an increase in demand from employees for flexible working patterns. However, I found very little evidence of this. An analysis of the types of roles occupied by graduates, alongside qualitative data from the survey and interviews suggests that the career trajectories of some respondents were apparently hostage to the funding regimes of various organisations. Jenny is typical of this, a female from a disadvantaged socio-economic background, was aged 25 when she entered university after completing an Access to HE course. She was a social studies respondent with a first class honours degree. After graduation she worked as 
an Administration Assistant, for six months - a role she had whilst in university. She then acquired employment as a project worker in a local regeneration area for the next 18 months until the European funding for her employment ceased. She was then unemployed for three months. Whilst the funding for the project returned in year three, there was only space for a project administrator and a project manager. She was unsuccessful when applying for the project manager role but instead was offered the administration role. She reported that whilst she enjoyed working on the project she was unhappy in her new role, she was still doing much of the work she had done before as project worker.

Jenny also reported being concerned both about both the gaps in her CV (whilst she was unemployed and waiting to start her next funded role), and the change in her job title (from project worker to project administration). Whilst a change in job titles, and small periods of unemployment may not seem like a major concern, this could make a difference for a graduate trying to compete against other graduates in an insecure labour market. She was particularly worried about the latter as she suggested that this may affect her ability to gain project officer roles in the future. This regional cohort of graduates, who in the most part were mature students and from socially disadvantaged backgrounds, appeared to understand that a graduate rich labour market may mean that a typical career pattern will contain fluctuations between being in and out of employment (Otto, Hoffmann-Biencourt, and Mohr, 2011). However, the graduates who were interviewed for this study were, for the most part concerned that they might be stuck in a cycle of temporary employment.

In a report for the ESRC, Vaitilingam (2009: 5) stated that the recession had increased uncertainty in economic markets and hampered the rate of hiring. All but one interviewee in this study reported being frustrated with the economic recession, whilst three graduates from disadvantaged economic backgrounds stated that their trajectory had either been disrupted e.g. graduate or non-graduate employment followed by periods of unemployment before being employed again [Hannah; Jenny] or limited to being employed on a temporary basis or undertaking a position with a zero hour contract [Karen]. This is in part consistent with research by Standing (2011) who asserted that the recession would be more likely to affect those from economically disadvantaged backgrounds. However, whilst Standing was referring to individuals without qualifications, this small scale research study supports his observations that previous economic status would be an indicator of whether you were likely to be working on a temporary basis. Temporary employment, as might be expected, also influenced whether a graduate's trajectory would be discontinuous e.g. having intervals or gaps. The main reason for disruptions in the trajectories of this graduate cohort was that cuts had been made in funding for local authority and third sector projects (the trajectory of Jenny is a good example here). Whilst the recession effect was not as noticeable as expected in terms of increasing unemployment, there were high levels of temporary contracts, particularly for the least advantaged graduates. Future research, when the economy is more buoyant, could illuminate whether these discontinuous trajectories are influenced by the economic recession, or if they constitute a further example of how non-traditional students have less favourable employment outcomes.

\section{Institutional differences}

Some significant institutional differences were found amongst my own sample of graduates. For instance graduates from the distance learning institution were more likely to go on to postgraduate study, when compared to the other two universities. This could be explained by their pattern of study e.g. they were used to studying whilst working. Further differences were found when comparing levels of multiple outcomes as there were very few distance learning graduates with this trajectory, compared with 
one third of respondents from the traditional university and almost half of the post 1992 respondents. Additional analysis of the data found that graduates from the post 1992 institution were also more likely to be working in temporary employment, to have periods of unemployment, and to have the greatest difficulty in finding and settling into graduate roles. It should be noted that this study was not able to compare a full range of institutions as North Wales does not currently have an elite or a Russell Group institution; this study concentrated on graduates from a traditional university, a post 1992 university and a distance learning institution. Thus, overall, my findings were consistent with a much cited study by Chevalier and Conlon (2003) who found that institutional differences tended to be more pronounced when elite universities are compared against other types of institutions, as opposed to traditional versus post 1992 institutions.

\section{Subject differences}

Despite this small sample of three degree subjects, there were differences. For instance self-employment was often an alternative trajectory for business graduates. Data from the DLHE survey in 2007/08 showed that three per cent of graduates were self-employed and that in 2010/11 this had risen to five percent. The respondents in this North Wales study showed similar levels, but also, after analysing their responses it was noted that half of the above respondents had parents or close family and friends who had started their own business. This finding supports evidence from a study by Hjarnø (2006) who evaluated the experiences of immigrants in Western Europe. His analysis indicates that the habitus that the migrants bring with them plays an important role in determining whether or not they will consider self-employment or look for waged work. Whilst this study focused on graduates, as opposed to immigrants, respondents who had parents who were self-employed would have spent a considerable amount of time being around their family business. There may be a link between self-employment and habitus as the respondents may have been used to seeing self employment being fitted around family life, have noted the late nights and long hours that their parents worked and even seen some of the practical elements of running a business first hand, e.g. filling in tax returns or chasing outstanding accounts.

Family influence was also an important factor for engineering graduates. The typical engineering student and subsequent graduate, according to HESA statistics and supported by my own research, was male, under the age of 25 , and generally from a middle-class background. I also observed that the majority had a family background in that specific field. In support of a study by Reay, Crozier and Clayton (2010) on workingclass students making the transition into higher education, my data showed that entry into the engineering field was greatly aided by having a father who had worked in this employment sector. One respondent, Jonathon, discussed how he gained a great deal of informal knowledge regarding mechanics when he was growing up as he would be around his father and his father's work colleagues whilst they were working. A further engineering respondent, Paul, outlined how after completing his course he was unemployed. However what is interesting is that he explicitly states that although he was out of work he used the time to work with his father to develop key engineering skills. Whilst the skills they developed were not outlined in any detail, it is notable that after this time Paul reported in year two that he went onto undertake a MSc in Electrical Studies for a two year period and when asked about his current or recent circumstances, he was working as a Quality Manager, whilst combining this role with further study.

When all three subjects are compared, social studies graduates had the most varied trajectories. For instance, whilst graduates from all three subjects had multiple outcomes or temporary employment, this was the outcome for over half of social 
studies graduates (compared with only one engineering graduate, and one quarter of business graduates). There is further variety in the types of employment in which social studies graduates are represented: either associate professional and technical occupations (graduate occupations) or administrative and secretarial occupations (nongraduate roles). In contrast, business graduates are mainly working as managers, directors and senior officials, or self-employed, whilst engineering graduates mainly worked in professional occupations. This differs slightly from the findings of the aforementioned Campaign for Social Science (2013) study which found that social studies graduates were most likely to be in professional occupations (there was no similar data on STEM graduates, but we should note that this research, as suggested in the title of the study, is a campaign with the aim of raising the profile of social studies thus there is likely to be little information regarding non-graduate employment). Whilst the variety of outcomes noted in the trajectories of social studies students suggests that this degree has particular transferability, these findings need to be tested against a wider range of subjects.

\section{Pre-entry characteristics influenced a graduate trajectory}

Whilst there were differences related to age, the most compelling differences were according to gender and social class. Full-time employment increased across the study period for both male and female graduates, although two thirds of males were employed full-time, compared with just under half of females. Postgraduate study showed similar patterns, except females were more likely to combine this with further study. As previously discussed, multiple outcomes were observed in the trajectories of one third of respondents, but within this data there are a number of key gender differences. For instance, female respondents were more likely to have multiple outcomes that included temporary employment. This finding is consistent with McCrobie's (2011) observation that temporary employment has traditionally been filled more by females than males, in part due to the perceived flexibility it offers mothers and those returning from maternity leave - women being more likely to take career breaks than men. However she also draws upon the aforementioned concept of the precariat, developed by Guy Standing (2011) that has emerged in recent years to describe both male and female employees who work on a flexible basis. Rosenberg and Lapidus (1999) also show that temporary workers are more at risk of workplace exploitation because employers see them as 'disposable workers.'

Whilst females were more likely to have multiple outcomes or be in temporary employment, there were higher levels of male graduates who had a period of unemployment in their trajectory. It should be noted that these periods of unemployment did not tend to last beyond six months, but what was notable was the male graduates who had been unemployed all told a similar story to the following respondent. Nick, a graduate who just fitted into the mature student category, had a family background comprised of a father who worked in maintenance and a mother who worked as a waitress. He talked about 'applying for about 15 graduate jobs'. He went on to say that he managed to get quite a few interviews for graduate jobs but 'I ended up being unsuccessful each time. I just kept on applying, but seemed to get nothing.' I asked the respondent why he thought this was and he answered simply: 'I wasn't saying the right things'. He went on to say that: 'I eventually just needed anything so just took bar work. But this did grate on me because I hadn't gone to university to do bar work, it made my degree feel like a waste of time.'

Nick self-identified as a non-traditional student due to his parents' occupations and their lack of engagement in any form of further study. Despite this they had both encouraged him to consider university. The problem, Nick suggested, was that he expected to get a graduate level job straight away due to his degree. However, 
increasingly employers are not only looking for degree qualifications, but also look for personal qualities, leadership potential, effective communication skills and the ability to work as part of a team. The respondent reflected on his graduate trajectory and suggested without prompting that maybe he had taken his degree qualification for granted in the sense that it was all he needed to gain suitable graduate employment. This was a theme I found when speaking with other male respondents I interviewed. An explanation for this is offered by Carl Gilleard, the chief executive of the Association of Graduate Recruiters. In an interview with the Guardian newspaper Gilleard, noted that 'When I talk to graduate recruiters about how impressive candidates applying for jobs are, I do pick up a sense that female graduates are a little more mature and focused, that they put together good applications' (Guardian, 2010). Gilleard went on to say that he felt that male students may perceive that a university education is enough to guarantee them the dream career (ibid).

Whilst I could not comment on that view of female candidates, I did find evidence that males, perhaps, were not as flexible as female graduates. For instance, Nick's comment that 'he hadn't gone to university to do bar work' was echoed by James and Mike. In comparison, female respondents reported that they were willing to try anything. For instance Jade undertook a variety of roles within her first few years after graduation as a receptionist, admin assistant followed by marketing assistant. When interviewed about this Jade suggested that she did not have any problems with doing such roles as it was: 'better to be working, than unemployed. You look much better as a candidate for other jobs if you have been in employment'. Three other female respondents also stated that they realised that they would need to progress through a number of 'stepping stone jobs' in order to develop work experience that would increase the currency of their degree qualification.

Various studies identified age and socio-economic class as factors that may influence post graduation experiences (see Purcell, Pitcher and Sim, 1999; Brennan and Shah, 2003 for further details). When the experiences of North Wales graduates were evaluated, specific patterns and differences according to either demographic were not easily identifiable. However, after further reflection, despite the fact that there were lower levels of respondents from these particular categories, it was noted that younger respondents who were in NS-SEC Analytic classes I-III e.g. Higher and Lower managerial, administrative and professional occupations and Intermediate occupations were the least likely to have multiple outcomes, or to be employed on a temporary basis, or even to have trajectories that were interrupted by unemployment. If they did have multiple outcomes, or work on a temporary basis this was something that did not tend to last for more than a twelve month period. These findings partially support those from a study by Macmillan, Tyler and Vignoles (2013). They found that socioeconomic status affects the likelihood of a recent graduate accessing a top job e.g. those from higher SES family backgrounds are more likely to enter higher status occupations when compared to graduates from lower SES backgrounds.

\section{Mature graduates and their employability skills}

In response to findings from Lido et al (2008) and Stevenson et al (2011) who point to a lack of employability skills amongst non-traditional students I discussed this concept in interviews, outlining the vast range of skills that fall under this general umbrella. ${ }^{13}$ Mature graduates were more likely than younger graduates to point out that they had these prior to university. For instance: Eileen, a female mature student said: 'I work as a nurse. I think it would be a worry if I did not know how to communicate, if I was not aware that we should not use overtly medical language to a patient, but it was ok to do this with a doctor.' She went on to say 'I think I am little bit more advanced than the average graduate.' This was the main theme noted 
throughout interviews with mature graduates: a feeling that the employability agenda was not suitable for them as they had already gained a variety of skills throughout their working life, and as parents/carers etc. When I probed regarding whether these skills would be suitable for the graduate labour market, all but one mature graduate stated that they would be. Particular reference was made to budgeting and negotiation skills picked up during parenting: 'I struggled on a very small budget whilst in university. This skill has been vital when compiling and keeping on top of a project budget' [Hannah].

However, a number of mature graduates, or those from disadvantaged socioeconomic backgrounds did state that they would like to know how to write for specific audiences. As Eileen said: 'I understand how to make medical notes and I understand how to write essays, but I would have difficulty if I was younger and aiming to change jobs. All the reports I have ever seen are written differently. I think the new graduates of today need more practical help and support and not be talked to as if they are idiots'. With younger graduates there was support for the employability agenda, as they felt that it was important to understand what employers wanted from them. Those who had been employed suggested that there was a definite need for an emphasis on the types of qualities that graduate employers might need.

\section{Widening access to what?}

As over half of the sample of graduates for this study entered HE as a direct or indirect result of attempts to widen participation, this study has collected useful data regarding the outcomes of these nationwide policies. This study has supported previous research by Brown and Hesketh (2004) and Byrom and Lightfoot (2013) that showed how non-traditional students, when compared to traditional graduates, benefit from $\mathrm{HE}$ on a personal level e.g. the joy one receives from learning and achieving. Graduates who entered HE from non traditional backgrounds were more likely to report this sense of personal achievement: 'University has been wonderful. I've not only gained a degree, but since studying I have many answers to long standing questions, and now more questions' [Catherine]. Others mentioned further examples of how studying for a degree had changed them:

I feel much more confident in myself and my abilities [Nick].

I am a lot more critical about the views around me [Hannah].

I have been able to help my children so much more [Claire].

In contrast to various studies (i.e. Graham and Donaldson, 1999; Bamber and Tett, 2001 and Bowl, 2003) which state that non-traditional students are more likely to face difficulties in integrating into student life, constructing assignments and understanding academic language, interviews with my own cohort of similar students supported an alternative, more positive view. In support of research by Reay, Crozier and Clayton (2009) I found that all of my respondents who shared the characteristics of nontraditional students, appeared to relish their time at university and reported that they enjoyed writing about a variety of subjects and took an active part in seminars. All interviewees acknowledged that university was a difficult process, but mature graduates and interviewees who were first in their family to attend university all mentioned the valuable social networks that they had developed whilst in university. As found in a study by Hernadez and Dunlap (2013) on Hispanic women in the United States, these networks were used interchangeably for study and emotional support. Five unrelated interviewees - all females - mentioned that they, alongside other mature students provided moral support when needed; would work together to develop their subject knowledge; and would proof read each other's essays. As Eileen, a mature female student who was the first in her family to attend university, reported: 'We all 
helped each other, we were a team, a network of like minded people. We all wanted the same thing - to gain a degree - so we were happy to help each other.'

Despite being happy with the increased confidence and the cultural capital they had gained, the non-traditional students who took part in this study were also clear that they, like other respondents from more advantaged backgrounds, had entered university in order to gain a career:

I wanted to learn but I mainly came to university to increase my chances to earn a greater salary [David].

The lure of a graduate job encouraged me to attend university [Mike].

Unfortunately it was only those students who entered as non-traditional students who did not appear to reach their goal: 'l enjoyed doing my degree but it's not lead to a graduate job' [David] and 'I am still looking for a role that matches my graduate abilities' [Emma]. One male graduate from a disadvantaged background, outlined below, felt it hadn't been worth it for him to go to university: 'In my search for employment opportunities I have widened my geographical search to around twenty five miles (Chester) to forty miles (Liverpool) from my current location Prestatyn... Secondly, my search for better job opportunities has seen me looking at a variety of non-graduate job roles other than teaching...and a variety of graduate programmes with Network Rail, Barclays and Tesco. I have improved my eligibility to teach Mathematics by taking lower paid employment such as working as a teaching assistant in order to gain much needed experience within the classroom environment. I have also been applying for other employment opportunities that are non degree related in order to improve upon my teaching assistant salary... But we must address whether the opportunity of going to University to obtain a degree is still a viable option. The Labour government, under the reign of Tony Blair, thought education should be available to all and thus inflated the supply of employees with degrees and therefore devalued the importance of a degree. A university student takes their focus off the job market to achieve their degree, however from my experience employers would rather employ an individual that has spent the whole three years in the workplace' [Mike].

This extract highlights that whilst it is important to widen participation into HE, we should concentrate on what we are actually widening access to. In a report for the thinktank CentreForum, Michael Brown, former vice-chancellor of Liverpool John Moores University from 2000 to 2011, says that universities need to focus on student outcomes e.g. how many poorer students gain graduate level employment after graduation. As this paper has outlined, a disproportionate level of non-traditional students taking part in this study did not gain access to such roles, were working on a temporary basis or had a disrupted trajectory.

An explanation offered for a lack of access to higher status occupations was that whilst the non-traditional students in this study had developed strong ties in university with fellow students, they entered a graduate labour market with a lack of social networks, or 'the direct and indirect connections between individuals which result in a structure of social relationships' (Morris, 1989: 328). Around ten per cent of my respondents made some reference to the need to know people. Research suggests that the social capital possessed by graduates from economically disadvantaged families may be unsuited to the graduate labour market (Furlong and Cartmel, 2005; Thomas and Jones, 2007). Discussions with my respondents supported the aforementioned studies as the following respondent noted: 'My friends and family would not know about the jobs I am looking for so would not be able to recommend me'. [Sean]. Whilst all respondents spoke well of their parents and close friends, highlighting the emotional support they received when looking for work, they also 
recognised that their contacts would not always be helpful. As one female respondent from a disadvantaged background stated: 'I have plenty of personal contacts, a lot of people who could support me when I am trying to gain employment, but sadly these contacts are people from where I live, my parents, my family: they are not the decision makers'. [Jenny].

\section{Conclusion}

This ESRC-funded research with a regional cohort of graduates aimed to illuminate their long-term trajectories. It is acknowledged that these findings are based on a small, non-probability sample and the analysis of a small subset of subject groups and institutions. Thus it is recommended that the trajectories of graduates is tested against the outcomes of those from another region of the UK, against the full range of subject groups and institutions. Despite these limitations this study has constituted an important commentary on the gains made by non-traditional students beyond higher education.

The Dearing Report (1997: I.I) stated that 'the purpose of education is lifeenhancing: it contributes to the whole quality of life'. My research supports this having found that individuals from disadvantaged backgrounds tend to benefit from HE on a personal level, e.g. the joy one receives from learning and achieving. However, this study also found evidence that these graduates did not secure the economic prosperity promised by successive UK governments who promoted widening participation policies (Byrom and Lightfoot, 2012). Comments from such graduates instead paint a picture of disrupted trajectories e.g. multiple outcomes (both consecutive and concurrent), temporary employment and non-graduate employment: findings that echo research from Chevalier and Lindley (2006). Policies to encourage individuals to aim for a university education are important. However, even in an economic recession the 'returns' in terms of graduate jobs and access to postgraduate study via bursaries need to be readily available.

The study also found evidence that disrupted trajectories appeared to be influenced in some part by a lack of social capital. Many non-traditional students in this study appeared to be unaware of how important social networks are for progression. Norris (2011: 1) states that many individuals who would be defined as being non-traditional students saw this as cheating. I did not find evidence for this, but I did note that most non-traditional students who took part in this study focused more on gaining academic capital and less on acquiring cultural capital. The importance of family and peer support is noted in the literature on access to $\mathrm{HE}$, but now needs to be a recurring theme in strategies to enhance graduate opportunities. There are no easy answers regarding how to help graduates who may lack the required social networks. However, including yearly alumni events to give students the opportunity to network with past students, and discover how their studies have helped them progress their career could be a start. Such events could also include current postgraduate students as a way of highlighting any research bursaries that are available. A recommendation by Norris (2011: 1), whose research focused on further education colleges, states that universities could further help undergraduates build social capital by 'developing relationships with organisations that have high social and cultural capital'. These relationships could potentially lead to mentoring/advocacy schemes as well as opportunities for graduates to develop their knowledge of progression routes (ibid). Widening access policies opened the doors to the 'institution': they now need to do this beyond graduation. 
p. 43. Beyond graduation: The trajectories of graduates in North Wales

\section{Notes}

1. Two significant reports, Learning Works and Higher Education in a Learning Society (the Kennedy and Dearing reports - both published in 1997) are often cited as established and explaining Widening Participation policies (Jary and Jones, 2006).

2. North Wales does not currently have an elite or a Russell Group institution.

3. Business \& Administrative Studies is a JACS subject area that encompasses the following subjects: (NO) Broadly-based programmes within business \& administrative studies; (N1) Business \& management studies; (N2) Operational research; (N3) Financial management; (N4) Accountancy; (N5) Marketing \& market research; (N6) Industrial relations; (N7) Catering \& institutional management; (N8) Land \& property management; (N9) Transport, other business \& administrative studies and (NZ) Balanced combination (HESA, undated).

4. Engineering and Technology is a JACS subject area that encompasses the following subjects: (HO) Broadly-based programmes within Engineering \& technology; (H1) General engineering; (H2) Civil engineering; (H3) Mechanical engineering; (H4) Aeronautical engineering; (H5) Electrical engineering; (H6) Electronic engineering; (H7) Production engineering; (H8) Chemical engineering; (H9) Other engineering; (HZ) Balanced combinations; (J1) Minerals technology; (J2) Metallurgy; (J3) Ceramics \& glasses; (J4) Polymers \& textiles; (J5) Other materials technology; (J6) Maritime technology; (J8) Biotechnology and (J9) Other technologies (ibid).

5. Social Studies is a JACS subject area encompasses the following subjects: (LO) Broadly-based programmes within social studies; (L1) Economics; (L2) Politics; (L3) Sociology; (L4) Social policy; (L5) Social work; (L6) Anthropology; (L7) Human \& social geography; (L9) Others in social studies (ibid).

6. A questionnaire is sent to graduates at their home address, and/or a link to an online version emailed.

7. This is lower than was expected, but is due to a large number of Business and Administration graduates being from outside of the UK.

8. This meant that there was a response rate of 16 percent. This exceeding low response rate was expected as I was contacting graduates four years after graduation using institutional records. It was expected that many potential respondents may have changed their postal and email addresses. This was confirmed due to there being a total of 55 emails and letters being returned.

9. The response rates of the other institutions cannot be provided as a sample frame was not possible.

10. As the data was collected over a six month period it is noted that some graduates outlined their circumstances four years after graduation, whilst others were outlining their situation close to four and a half years after graduation. For consistency I will record this data as being the circumstances of graduates four years after graduation.

11. HESA Publication Categories are available from: http://www.hesa.ac.uk/index.php?option=com content\&task=view\&id=573\&/temi $\mathrm{d}=233$.

12. All names of respondents have been anonymised. 
p. 44. Beyond graduation: The trajectories of graduates in North Wales

13. The following link from the University of Kent's Careers Service page provide a good outline of these skills http://www.kent.ac.uk/careers/sk/skillsmenu.htm. This link was shown to all graduates during interviews.

\section{Acknowledgements}

I would like to thank the anonymous referee for their extremely helpful comments on an earlier draft of this paper. I would also like to thank the Editor and my colleagues for their kind support.

* Correspondence Address: Dr Teresa Crew, Bangor University. Email: t.f.crew@bangor.ac.uk

\section{References}

Bamber, J. and Tett, L. (2001) Ensuring integrative learning experiences for nontraditional students in Higher education. Journal of Widening Participation and Lifelong Learning, 3, 1, 8-18.

Barrow, C. (2011) When 'non-traditional' is the norm: a new set of challenges. Available www.lancaster.ac.uk/fss/events/hecu5/docs/.../Barrow,\%20Charlotte.doc [Accessed: 6/12/2014].

Bathmaker, A., Ingram, N. and Waller, R. (2013) Higher education, social class and the mobilisation of capitals: recognising and playing the game. British Journal of Sociology of Education, 34, 5-6, 723-743.

Benn, R. (1995) Higher education: Non-standard students and withdrawals. Journal of Further and Higher Education, 19, 3, 3-12.

Brennan, J. and Shah, T. (2003) Access to what? Converting education opportunity into employment opportunity. London: Centre for Higher Education Research and Information.

Brennan, J., Williams, R. and Blasko, Z. (2003) The English degree and graduate careers. London: Learning and Teaching Support Network (LTSN) English Subject Centre.

Brown, P. and Hesketh, A. (2004) The Mismanagement of Talent: Employability and Jobs in the Knowledge Economy. Oxford: Oxford University Press.

Byrom, T and Lightfoot, N. (2012) Transformation or Transgression? Institutional Habitus and Working Class Student Identity. Journal of Social Sciences, 8, 2, 126134.

Bourdieu, P. (1979) Distinction: Social Critique of the Judgment of Taste. Cambridge: Cambridge University Press.

Bourdieu, P. (1973) Cultural Reproduction and Social Reproduction. In: R. K. Brown (ed.) Knowledge, Education and Cultural Change. London: Tavistock.

Bowl, M. (2003) Flexible Friends: Beyond Formal Partnerships in Community Education. Journal of Access and Credit Studies, 4, 2, 90-101.

Campaign for Social Science (2013) What Do Social Science Graduates Do? Available at:https://campaignforsocialscience.org.uk/wpcontent/uploads/2013/10/Graduate-report-2013.pdf [Accessed: 6/12/2014].

Chevalier, A. and Conlon, G. (2003) Does it pay to attend a prestigious university? Working Papers 200320. Dublin: University College Dublin. Available at: http://cee.Ise.ac.uk/ceedps/ceedp33.pdf [Accessed: 11/11/2010]. 
p. 45. Beyond graduation: The trajectories of graduates in North Wales

Chevalier, A and Lindley, J. (2006) Over-Education and the Skills of UK Graduates. IZA Discussion Papers 2442. Institute for the Study of Labor. Available at: http://epubs.surrey.ac.uk/430993/1/Chevalier_Lindley_2009.pdf [Accessed: 11/11/2010].

David, M., Parry, G., Vignoles, A., Hayward, G., Williams, J., Crozier, G., Hockings, C. and Fuller, A. (2008) Widening participation in higher education. A Commentary by the Teaching and Learning Research Programme. Available at: http://www.tlrp.org/pub/documents/HEcomm.pdf [Accessed: 15/10/2014]

Dearing, R. (1997) Higher Education in the Learning Society. London: National Committee of Inquiry into Higher Education.

Egerton, M. (2001) Mature Graduates II: Occupational Attainment and the Effects of Social Class. Oxford Review of Education, 27, 2, 271-286.

Field, J. and Morgan-Klein, N. (2010) Studenthood and identification: higher education as liminal transitional space. Paper presented ate the 40th Annual Conference of Standing Conference on University Teaching and Research in the Education of Adults (SCUTREA), Looking back, looking forward: learning, teaching and research in adult education past, present and future. University of Warwick, July 7th 2010.

Furlong, A. and Cartmel, F. (2005) Graduates from Disadvantaged Families: Early Labour Market Experiences. Bristol: The Policy Press.

Graham, S. and Donaldson, J. (1999) Adult students' academic and intellectual development in college. Adult Education Quarterly, 49, 3, 147 - 161.

The Guardian (2010) Unemployment fears grow for 'hopeless' UK male graduates. Sunday, 4 July $4010 . \quad$ Available at: http://www.theguardian.com/education/2010/jul/04/unemployment-malegraduates [Accessed: 26/11/2010]

Hernandez, P. and Dunlap, D. (2012) Para crecer: Sucessful higher education strategies used by Latina students. In: Social Inclusion and Higher Education by Tehmina Basit (Editor), Sally Tomlinson (Editor). Bristol: The Policy Press.

Higher Education Funding Council for Wales (2010) Press Release. Diverse student body in Welsh universities. Available at: http://www.hefcw.ac.uk/documents/news/press releases/2010\%20press\%20re leases/15\%2004\%2010\%20\%20performance\%20indicators\%202008\%2009\%20-\%20english.pdf [Accessed: 22/02/2014].

Higher Education Funding Council for Wales (2013) Changes to the funding of the National Student Survey and Destination of Leavers from Higher Education survey in directly funded further education institutions from 2014/15. Available at: https://www.hefcw.ac.uk/documents/publications/circulars/circulars 2013/W1 3\%2014HE\%20Changes\%20to\%20the\%20funding\%20of\%20NSS\%20and $\% 20 \mathrm{DL}$ HE\%20in\%2OFEI\%202014_15.pdf [Accessed: 22/02/2014].

Higher Education Statistical Agency (2011) Bespoke data request. Statistical data on the First destinations of graduates in Business, Engineering and Social studies, from the request targets institutions 2007/08.

Hjarnø, J. (2006) Immigrants as small businessmen: a comparative analysis of the extent of self employment among Danish Pakistanis, Turks and ex-Yugoslavs. Available at: http://rauli.cbs.dk/index.php/dansksociologi/rt/metadata/621/0 [Accessed: 01/02/2014].

Jary, D. and Jones, R. (2006) Overview of Widening Participation Policy and Practice. In: D. Jary, and R. Jones (Eds.) (2006) Perspectives and Practice in Widening Participation in the Social Sciences. Birmingham: C-SAP.

Kennedy, H. (1997) Learning Works: Widening Participation in Further Education. London: Widening Participation Committee of the Further Education Funding Council. 
p. 46. Beyond graduation: The trajectories of graduates in North Wales

Leathwood, C. and O' Connell, P. (2003) 'It's a Struggle': the construction of the 'new student' in higher education. Journal of Education Policy 18, 6, 597-615.

Lido, C., May, S., Morgan, J. and Stuart, M. (2008) Student diversity, extra-curricular activities and perceptions of graduate outcomes. York: HEA. Available from: http://www.heacademy.ac.uk/assets/documents/resources/publications/Stuart ECA_Final.pdf [Accessed: 09/04/2014].

Macmillan, L., Tyler, C. and Vignoles, A. (2013) Who gets the Top Jobs? The role of family background and networks in recent graduates' access to high status professions. Department of Quantitative Social Science Working Paper No. 13, 15. London: Institute of Education, University of London.

McCrobie, H. (2011) The precariat and Mad Men secretaries: temping under the Tory government. 50:50. Inclusive Democracy. Available at: http://www.opendemocracy.net/5050/heather-mcrobie/precariat-and-mad-mensecretaries-temping-under-tory-government [Accessed: 17/09/2013]

McGivney, V. (2004) Understanding Persistence in Adult Learning, Open Learning, 19, 1, 33-46.

Milburn, A. (2012) University Challenge: How Higher Education Can Advance Social Mobility, a progress report by the Independent Reviewer on Social Mobility and Child Poverty. London: Cabinet Office.

Moore, J., Sanders, J. and Higham, L. (2013) Literature Review of Research into Widening Participation to Higher Education. Bristol: HEFCE.

Morey, A., Harvey, L., Williams, J., Saldaña, A., Mena, P., Watson, S. and MacDonald, M. (2003) HE Careers Services and Diversity: How Careers Advisory Services can enhance the employability of graduates from non-traditional backgrounds. Manchester: Higher Education Careers Service Unit (HECSU).

Morris, D. (1989) A study of the language contract and social networks in Ynys Môn, Contemporary Wales, 3.

Newson, C., McDowall, A. and Saunders, M.N.K. (2011) Understanding the support needs of mature students. Guildford: University of Surrey.

Norris, E. (2011) Not Enough Capital? Exploring Education and Employment Progress in Further education. London: Royal Society of Arts.

Office of National Statistics (2013) Graduates in the UK Labour Market 2013. Available at: $\quad$ http://www.ons.gov.uk/ons/rel/Imac/graduates-in-the-labourmarket/2013/rpt---graduates-in-the-uk-labour-market-2013.html [Accessed: 07/11/ 2013].

Otto, K., Hoffmann-Biencourt, A. and Mohr, G. (2011) Is there a buffering effect of flexibility for job attitudes and work-related strain under conditions of high job insecurity and regional unemployment rate? Economic and Industrial Democracy. 32, 4, 609-630.

Pennington, M., Mosley, E. and Sinclair, R. (2013) AGCAS/AGR Graduate Success Project: an investigation of graduate transitions, social mobility and the HEAR. Available from: http://www.agcas.org.uk/assets/1519-Graduate-Success-Projectdownloads [Accessed: 26/01/14].

Phellas, C., Bloch, A. and Seale, C. (2012) Structured methods: interviews, questionnaires and observation. In: Seale, Clive, (Ed) Researching Society and Culture (3rd Edition). Thousand Oaks, CA: Sage.

Power, S., Edwards, T., Whitty, G. and Wigfall, V. (2003) Education and the Middle Class. Buckingham: Open University Press.

Purcell, K.. Elias, P., Atfield, G., Behle, H., Ellison, R. and Luchinskaya, D. (2013) Transitions into employment, further study and other outcomes, The Futuretrack stage 4 Report. Manchester/Coventry: HECSU/Warwick Institute for Employment Research.

Purcell, K., Pitcher, J. and Simm, C. (1999) Working Out? Early graduate experiences of the labour market. Manchester: CSU Ltd. 
Reay, D., Crozier, G. and Clayton, J. (2009) Strangers in paradise'? Working Class students in Elite Universities. Sociology, 43, 6, 1103-1121.

Reay, D., David, M.E. and Ball, S. (2005) Degrees of Choice: social class, race and gender in higher education. London: Trentham Books

Reay, D. (2001) Finding or losing yourself?: Working class relationships to education Journal of Education Policy, 16, 4, 333-346.

Reay, D. (1998) Class Work: Mothers' involvement in children's schooling. London: University College Press.

Rosenberg, S. and Lapidus, J. (1999) Contingent and Non-Standard Work in the United States: Towards a More Poorly Compensated, Insecure Workforce. In: Felstead \& Jewson (eds) Global Trends in Flexible Labour. Basingstoke: MacMillan.

Smith, J., McKnight, A. and Naylor, R. (2000) Graduate Employability: Policy and performance in Higher Education in the UK. Economic Journal, 110, 382-411.

Standing, G. (2011) The Precariat: The New Dangerous Class. London: Bloomsbury Academic.

Stevenson, J. and Clegg, S. (2011) Possible selves: students orientating themselves towards the future through extracurricular activity. British Educational Research Journal, 37, 2, 231-246.

Stuart, M., Lido, C., Morgan, M., Solomon, L. and Akroyd, K. (2008) Widening participation to postgraduate study: decisions, deterrents and creating success. York: Higher Education Academy.

The Organisation for Economic Co-operation and Development (2002) Taking the Measure of Temporary Employment. OECD Employment Outlook 2002.

Thomas, L. and Jones, R. (2007) Ten year review of the Sutton Trust summer schools. London: Sutton Trust.

Thomas, L., May, H., Harrop, H., Houston, M., Knox, H., Lee, M.F., Osborne, M., Pudner, $\mathrm{H}$. and Trotman, C. (2005) From the margins to the mainstream: embedding widening participation in higher education. London: Universities UK.

Thomas, L. and Quinn, J. (2007) First Generation Entry into Higher Education. Maidenhead: SRHE \& OUP.

Thomas, L. (2005) Higher education widening participation policy in England: transforming higher education or reinforcing elitism? Ad-Lib, 29, Article 1. Available online at: https://www.ice.cam.ac.uk/institutemedia/pdfs/adlib/adlib29.pdf [Accessed: 22/02/2014).

Tibby, M. (2012) Employer and student perceptions of employability. York: Higher Education Academy.

Tomlinson, M. (2007) Graduate Employability and Student Attitudes and Orientations to the Labour Market. Journal of Education and Work, 20, 4, 285-304.

Vaitilingam, R. (2009) Recession Britain: Findings from economic and social research. The Economic and Social Research Council. Available at: http://www.esrc.ac.uk/_images/Recession_Britain_tcm8-4598.pdf [Accessed: 22/02/2014]

Wakeling, P. and Kyriacou, C. (2010) Widening Participation from Undergraduate to Postgraduate Research Degrees: a Research Synthesis. Swindon: ESRC and NCCPE. 